\title{
PENGARUH WORD OF MOUTH DAN KUALITAS PELAYANAN TERHADAP KEPUTUSAN PENGGUNAAN JASA GOJEK DI KOTA DENPASAR
}

\author{
I K.A.W. Purnawan ${ }^{1}$, I N. Suarmanayasa ${ }^{2}$ \\ 1,2Jurusan Manajemen, Universitas Pendidikan Ganesha, Singaraja \\ e-mail: Ikomangaguswirapurnawan27@undiksha.ac.id¹, nengah.suarmanayasa@undiksha.ac.id²
}

\begin{abstract}
Abstrak
Penelitian bertujuan untuk menguji bagaimana pengaruh antara word of mouth dan kualitas pelayanan secara parsial ataupun simultan terhadap keputusan penggunaan jasa Gojek di Kota Denpasar. Dalam penelitian ini menggunakan rancangan penelitian kuantitatif kausal, dimana pelanggan Gojek di Kota Denpasar sebagai subjek penelitian, word of moth dan kualitas pelayanan serta keputusan penggunaan sebagai objek penelitian. Pengambilan sampel di dalam penelitian ini yaitu dengan menggunakan teknik non-probability sampling dan purposive sampling. Adapun jumlah sampel yang ambil dalam penelitian ini sebanyak 120 responden. Data yang yang dikumpulkan menggunakan metode kuesioner serta selanjutnya akan dianalisis menggunakan metode regresi linier berganda. Adapun hasil dari penelitian ini adalah: (1) word of mouth dan kualitas pelayanan secara bersama-sama memiliki pengaruh yang signifikan terhadap keputusan penggunaan jasa Gojek di Kota Denpasar. (2) word of mouth memiliki pengaruh yang positif dan signifikan terhadap keputusan penggunaan jasa Gojek di Kota Denpasar. (3) Kualitas pelayanan memiliki pengaruh yang positif dan signifikan terhadap keputusan penggunaan jasa Gojek di Kota Denpasar.
\end{abstract}

Kata Kunci: keputusan penggunaan, kualitas pelayanan, word of mouth

\begin{abstract}
This study intended to examine the effect simultaneously and partially between word of mouth and service quality on the usage decicion Gojek services in Denpasar City. This research design of this research used casual quantitative research. The subject of this research is Gojek's costumer, and object in this research are word of mouth, quality service and usage decision. The sample collection technique uses in this research is non-probabillity sampling and purposive sampling. The number of samples used was 120 respondents. The data collection technique in this research was a questionnaire and analysis technique used was multiple linear regression analysis. The results of this research are: (1) word of mouth and service quality with simultaneously have significant effect on the usage decision Gojek services in Denpasar City. (2) word of mouth has positive and significant effect on the usage decision Gojek services in Denpasar City. (3) Service quality has positive and significant effect on the usage decision Gojek services in Denpasar City.
\end{abstract}

Keywords: usage decisions, service quality, word of mouth

\section{Pendahuluan}

Transportasi adalah suatu hal yang sangat penting peranannya dalam pertumbuhan ekonomi di Indonesia saat ini. Semakin bertambahnya jumlah penduduk maka semakin banyak pula diperlukannya transportasi untuk melakukan segala aktifitas sehari-hari. Dengan fenomena tersebut maka bisnis dibidang transportasi akan sangat menjanjikan. Transportasi madalah kegiatan atau aktivitas mengangkomodir atau membawa sesuatu dari tempat satu kealinnya (Morlok, 1981). Dewasa ini kebutuhan akan transportasi menuju arah baru, dimana jasa transportasi yang berbasis konvensional sudah mulai terkikis oleh keberadaan jasa tranportasi berbasis online, hal ini erat kaitannya dengan era globalisasi dimana segala aspek kehidupan berubah dari konvensional ke online atau digital. Gaya online tidak bisa dilepaskan dari gaya 
kehidupan masyarakat dimana digitalisasi memberikan kemudahan serta efesiensi waktu terhadap konsumen. Transportasi online memberikan kemudahan serta kenyamanan terhadap konsumen dengan memilih waktu dan tempat yang sesuai dengan keperluan konsumen, hal ini sangat berbeda dengan transportasi konvensional yang mana perlu tempat untuk mangkal atau langsung menghampiri calon konsumen untuk menawarkan jasa, sedangkan transportasi online bisa diakses oleh calon konsumen dimanapun dan kapanpun melalui aplikasi mobile di smartphone. Dimana pada era sekarang setiap orang pasti sudah memiliki smartphone dan dapat terhubung ke internet. Dengan demikian banyak pengguna internet yang berada di Indonesia maka dapat disimpulkan bahwa transportasi online akan semakin berkembang seiring dengan perkembangan jaman.

Pada saat ini banyak jenis transportasi online yang berkembang di dunia, khususnya di Indonesia terdapat transportasi online yang sudah tidak asing lagi untuk didengar yaitu Gojek, dimana Gojek merupakan salah satu media layanan berbasis pesanan yang berasal dari Indonesia. Perusahaan ini dibentuk oleh Nadiem Makarim tahun 2010 di ibu Kota Jakarta, dan merupakan pelopor transportasi online yang ada di Indonesia. Gojek bergerak dibidang usaha jasa dimana 5 fitur utamanya adalah pelayanan antar jemput penumpang atau GO-RIDE, pesan antar makanan atau GO-FOOD, pelayanan pengiriman barang atau GO-SEND, pelayanan berbelanja atau GO-SHOP dan pelayanan pembelian obat dan kesehatan lainnya atau GO-MED. Selain Gojek juga terdapat perusahaan transportasi online di Indonesia yaitu Grab, yang mana Grab merupakan pesaing Gojek dalam usaha transportasi online, dimana ke dua nya memiliki jenis usaha dan fitur-fitur yang hampir sama. Adapun top brand index dibidang transportasi online yang dihimun dari tahun 2017 sampai dengan tahun 2020, Gojek menjadi top brand dalam bidang transportasi online 3 kali dalam 4 tahun terakhir, pada tahun 2017 dengan presentasi 59,2\% dan Grab 28,2\% sedangkan pada tahun 2018 Gojek kalah dengan presentase 44,9\% sedangkan Grab 48\%. Akan tetapi ditahun berikutnya tahun 2019 dan 2020 Gojek menjadi top brand dalam bidang transportasi online.

Dengan persaingan yang begitu kompetitif diperlukannya kegiatan pemasaran yang efektif untuk Gojek agar calon konsumen mau melakukan keputusan penggunaan jasa Gojek. Menurut Machfoedz (2010) menyatakan bahwa seharusnya untuk proses pengambilan suatu keputusan adalah rangkaian proses dimana diawali dari pemilihan berbagai alternative pilihan yang tersedia dan diakhiri dengan memilih alternatif yang sesuai dengan keperluan tertentu dan menetapkan pilihan yang dianggap paling mengguntungkan bagi pemilih. Sedangkan pendapat dari Setiadi (2008:415) mengemukakan keputusan penggunaan merupakan serangkain proses dimana menggabungkan pengalaman serta pengetahuan untuk menilai alternatif pilihan yang tersedia dan memilih salah satu diantara pilihan tersebut. Begitu banyak faktor yang dapat mempengaruhi calon konsumen untuk melakukan keputusan penggunaan, berikut beberapa faktor diantaranya adalah: Garylda (2014) menyatakan bahwa keputusan penggunaan dipengaruhi oleh kepercayaan merek dan kualitas pelayanan. Iknesya dan Arjuna (2019) memaparkan bahwa keputusan penggunaan dipengaruhi brand image dan word of mouth. Sedangkan dari Lukiana (2018) memaparkan jika keputusan penggunaan bisa dipengaruhi oleh citra perusahaan, word of mouth, kualitas produk dan kualitas pelayanan. Serta dari Sari dan Dwiya (2018) mengemukakan bahwa keputusan pembelian atau penggunaan dipengaruhi oleh kualitas pelayanan, pemasaran digital dan komunikasi mulut ke mulut. Berdasarkan hal tersebut maka dapat ditentukan jika variabel-variabel yang mempengaruhi variabel keputusan penggunaan adalah: brand trust, kualitas pelayanan, brand image, komunikasi mulut ke mulut, citra perusahaan, kualitas produk dan pemasaran digital. Dalam penelitian ini penulis hanya akan memfokuskan menggunakan variabel mulut ke mulut dan kualitas pelayanan saja, dikarenakan variabel mulut ke mulut memiliki pengaruh yang positif dan signifikan dalam penelitian Iknesya dan Arjuna (2019) dan Sari dan Dwiya (2018). Serta variabel kualitas layanan memiliki pengaruh yang positif dan signifikan dalam penelitian Garylda (2014), Lukiana (2018) dan Sari dan Dwiya (2018). 
Word of mouth atau komunikasi mulut ke mulut merupakan aktivitas pemasaran yang mana dua atau lebih individu saling menukar informasi melalui komunikasi langsung, media, ataupun perangkat elektronik yang didasari oleh pengalaman atas penggunaan suatu produk atau jasa (Kotler dan Keller 2009:512). Pemaksimalan suatu respon pengguna dengan memberikan layanan yang baik demi mendapatkan opini yang ditersebar kepada calon pengguna lainnya, Gojek berusaha memberikan layanan prima dari cara kerja pengemudi yang di bergabung menjadi mitra kerja Gojek. Sehingga setelah calon konsumen mendapatkan informasi dari suatu jasa yang didapatkan melalui percakapannya dengan orang-orang terdekatnya dan ingin mencoba jasa atau produk tersebut maka calon konsumen lainnya akan melakukan keputusan penggunaan. Dalam penelitian yang dilaksanakan oleh Iknesya dan Arjuna (2019) menyatakan bahwa word of mouth berperan positif dan signifikan terhadap keputusan penggunaan. Serta penelitian dari Sari dan Dwiya (2018) menyatakan jika word of mouth memiliki peran yang positif dan signifikan kepada keputusan penggunaan. Namun menurut penelitian yang dilaksanakan oleh Lukiana (2019) menyatakan bahwasanya word of mouth memiliki peran secara negatif dan tidak signifikan kepada keputusan penggunaan, serta penelitian oleh Hastuti (2018) menunjukan jika word of mouth memiliki peran yang tidak signifikan terhadap keputusan pembelian.

Kualitas pelayanan yang sangat baik tentunya akan memberikan suatu dampak dorongan kepada konsumen untuk konsumen bisa membangun suatu hubungan baik kepada pihak penyedia jasa sehingga akan memungkinkan suatu perusahaan agar mampu memahami dengan benar harapan dan kebutuhan dari konsumen, yang mana akhirnya kepuasan dari pengguna jasa akan bisa digapai. Kualitas pelayanan merupakan nilai dari keseluruhan transaksi jangka panjang yang mana mencermikan nilai yang diberikan perusahaan kepada konsumen. Konsumen dalam melakukan transaksi pembelian atau penggunaan suatu produk maupun jasa akan selalu berharap mendapatkan sesuatu yang lebih baik dari apa yang dikeluarkan oleh konsumen. Sehingga jika apa yang didapatkan konsumen lebih baik dari harapannya maka konsumen tersebut akan merasa puas dan akan terus menggunakan jasa atau produk tersebut. Kualitas iyalah dimana suatu keadaan yang selalu berubah-ubah dan berhubungan terhadap produk atau jasa dan keadaan yang memenuhi atau melebihi harapan (Tjiptono, 2006). Dalam penelitian yang dilaksanakan oleh Garylda (2014) memaparkan jika kualitas layanan memiliki peran yang positif dan signifikan terhadap variabel keputusan penggunaan, serta penilitan lain oleh Lukiana (2018) serta penelitian Sari dan Dwiya (2018) juga menyampaikan kualitas layanan memiliki peran yang positif dan signifikan terhadap variabel keputusan penggunaan. Akan tetapi berbeda dengan penelitian Nasution dan Maksum (2018) yang menyatakan jika kualitas layanan tidak memiliki peran terhadap variabel keputusan penggunaan. Kunci akhir adalah keputusan penggunaan dari konsumen, karena pada dasarnya seberapapun canggih yang ditawarkan sebuah teknologi dari perusahaan namun tanpa disesuaikan dengan kebiasaan konsumen, gaya hidup, kebutuhan konsumen serta tuntutan dari apa keinginan konsumen tentu saja akan berbanding terbalik dengan apa yang diharapkan perusahaan.

Word of mouth atau komunikasi mulut kemulut merupakan suatu keadaan dimana antara individu satu dengan yang lainnya saling menukarkan informasi berkaitan dengan seuatu yang mereka anggap bagus sehingga bisa mempengaruhi calo konsumen lain untuk melakukan keputusan penggunaan dan bisa membuat suatu bisnis menjadi sukses. (Supranto dan Nanda, 2011). Sedangkan kualitas pelayanan memiliki fungsi penting untuk mencapai kepuasan pelanggan. Pelayanan yang maksimal akan membuat rasa kepuasan konsumen untuk menggunakan atau membeli kembali suatu barang/jasa yang ditawarkan perusahaan. Dengan adanya kualitas layanan yang baik serta strategi word of mouth maka akan sangat mempengaruhi konsumen dalam melakukan keputusan penggunaan. Hal ini sudah dibuktikan dalam penelitian Saputra \& Ardani (2020) yang mana menyatakan jika variabel komunikasi mulut ke mulut dan kualitas layanan sama-sama memiliki peran secara positif dan signifikan 
terhadap variabel keputusan penggunaan. Penelelitian lain oleh Sari dan Dwiya (2018) yang menyatakan kalau komunikasi mulut ke mulut dan kualitas layanan memiliki peran yang positif dan signifikan terhadap variabel keputusan penggunaan.

Word of mouth atau komunikasi mulut ke mulut yang bisa membuat suatu percakapan yang baik, dimana orang-orang akan mulai bertanya dengan orang terdekatnya perihal mutu suatu barang atupun jasa sebelum mereka menggunakannya. Dengan demikian komunikasi mulut ke mulut bisa mempengaruhi seseorang untuk melaukan keputusan penggunaan. (Sernovitz, 2009:19). Sejalan dengan penelitian Iknesya dan Arjuna (2019) serta Sari dan Dwiya (2018) yang menyatakan bahwa variabel komunikasi mulut ke mulut memiliki peran yang positif dan signifikan terhadap variabel keputusan penggunaan.

Kualitas pelayanan adalah sebuah ukuran atau evaluasi terhadap segala sesuatu yang menjadi keinginan ataupun kebutuhan konsumen dimana jika konsumen sudah merasa puas akan apa yang mereka dapatkan setelah menggunakan suatu produk maupun jasa, maka konsumen tersebut akan terus menggunakannya. Sama halnya dengan penelitian yang dilaksanakan oleh Arifin (2017) yang memaparkan kan jika kualitas layanan memiliki peran yang positif dan signifikan terhadap variabel keputusan penggunaan. Sejalan atas penelitian yang dilaksanakan oleh Amrullah (2016) yang memaparkan jika kualitas pelayanan berperan secara positif dan signifikan terhadap variabel keputusan penggunaan. Artinya jika nilai suatu layanan semakin baik maka konsumen tertarik untuk menggunakan suatu jasa atau produk tersebut. Oleh karena hal tersebut konsumen dalam melakukan penggunaan jasa Gojek di Kota Denpasar memiliki peranan yang sangat penting dalam keberlangsungan dari usaha Gojek tersebut. Berdasarkan uraian latar belakang diatas, disini penulis tertarik melakukan penelitian dengan judul: "Pengaruh word of mouth dan kualitas pelayanan terhadap keputusan penggunaan jasa Gojek di Kota Denpasar". Adapun tujuan penelitian ini adalah untuk menganalisis besar pengaruh dari: (1). Word of mouth dan kualitas pelayanan terhadap keputusan penggunaan jasa Gojek di Kota Denpasar. (2) Word of mouth terhadap keputusan penggunaan jasa Gojek di Kota Denpasar. (3) Kualitas layanan terhadap keputusan penggunaan jasa Gojek di Kota Denpasar.

\section{Metode}

Penelitian ini menggunakan desain penelitian kuantitatif kausal yang mana desain tersebut digunakan untuk menganalisis hubungan sebab akibat antar variabel bebas dengan variabel terikat (Sugiyono, 2013: 56). Data kuantitatif tersebut merupakan hasil dari kuesioner yang disebar sehingga mendapatkan hasil dari tabulasi jawaban responden pada kuesioner. Dalam penelitian ini memiliki tujuan untuk menganalisis pengaruh dari word of mouth dan kualitas pelayanan sebagai variabel independent terhadap keputusan penggunaan jasa Gojek di Kota Denpasar. Subjek yang dikaji di dalam penelitian ini adalah konsumen yang melakukan penggunaan jasa Gojek di Kota Denpasar. Sedangkan objek yang dikaji di dalam penelitian ini adalah word of mouth $\left(\mathrm{X}_{1}\right)$, kualitas pelayanan $\left(\mathrm{X}_{2}\right)$, dan keputusan penggunaan $(\mathrm{Y})$

Metode untuk mengumpulkan data di dalam penelitian ini adalah sebagai berikut: (1) Studi pustaka merupakan proses awal untuk mengumpulkan data serta pencarian informasi dari berbagai media, baik itu media konvensional seperti dokumen atau buku-buku referensi ataupun informasi dari media digital yang dapat membantu penelitian ini. (2) Metode Kuesioner adalah kegiatan menghimpun data dari responden yang mana bentuk kuesioner dalam penelitian ini berstruktur atau angket tertutup dengan jawaban pernyataan yang telah disiapkan dalam bentuk pilihan. Responden tidak perlu memberikan tambahan jawaban, responden hanya perlu menjawab pernyataan dengan 5 jawaban yang sudah tersedia, yang mana nantinya akan dapat memudahkan peneliti dalam mengelola dan menganalisis data. Skala yang digunakan dalam penyusunan kuesioner ini adalah skala likert, yang mana skala tersebut memiliki 5 tingkatan jawaban dan disusun menjadai suatu pernyataan yang diikuti oleh 5 respon jawaban. 
Pengambilan sampel yang nantinya akan digunakan sebagai data kuatitatif dalam sebuah penelitian haruslah sesuai dengan mekanisme pengambilan sampel, yang mana teknik sampling yang digunakan yaitu non-probability sampling yang mana teknik tersebut tidak memungkinkan untuk seluruh anggota populasi untuk menjadi (Sugiyono, 2009:84). Sampel yang dipilih menggunakan teknik yaitu purposive sampling, yang mana teknik tersebut menentukan sampel dengan adanya pertimbangan khusus atau kriteria tertentu sehingga responden layak dijadikan sampel. Kriteria tersebut adalah: Konsumen yang telah menggunakan jasa Gojek minimal 2 kali di Kota Denpasar. Karena responden sudah mengetahui pelayanan Gojek serta dari berbagai macam konsumen yang menjadi responden harus berumur 17-60 tahun, karena responden telah dianggap dewasa sehingga akan bisa menjawab pertanyaan yang diajukan oleh penulis. Dalam penelitian ini jumlah resonden yang digunakan sebanyak 120. Data yang diperoleh dari kuesioner kemudian akan di analisis menggunakan suatu metode yang disebut regresi linear berganda dimana pengolahan data dibantu sebuah program digital Statistical Package for Social Science (SPSS) 24.0 for Windows untuk memudahkan mengolah data penelitian. Alasan peneliti mengunakan analisis regresi linear berganda adalah karena dalam penelitian ini menganalisis pengaruh dari variabel independent yaitu word of mouth dan kualitas pelayanan terhadap variabel dependent keputusan penggunaan, serta dipakai untuk mengetahui sumbangan besar pengaruh antara varibel independent dan variabel inindependent yaitu word of mouth dan kualitas pelayanan sebagai variabel independent terhadap keputusan penggunaan sebagai variabel dependent.

Uji asumsi klasik harus dilakukan sebelum menguji serta menganalisis suatu data penelitian dengan model regresi dengan menggunakan program digital yaitu Statistical Package for the Sosial Science (SPSS). Uji asumsi klasik ini dipakai untuk mengetahui suatu persamaan analisis regresi linier berganda tersebut apakah bisa digunakan untuk mempredeksi variabel yang akan diteliti. Uji asumsi yang hendak digunakan yaitu: (1) Uji Normalitas, yang mana cara untuk mengetahui apakah suatu data terdistribusi normal dapat dilihat dari sebaran data pada sumbu diagonal suatu grafik. Adapun ketentuannya dijelaskan oleh Santoso (2001) sebagai berikut: a. Jika data yang tersebar berada pada garis diagonal serta mengekor pada arah garis diagonal, maka model regresi tersebut diasumsikan normal. b. Jika data yang tersebut tersebar jauh dari garis, atau bahkan tidak mengikuti garisnya tersebut, maka model regresi tersebut tidak dapat diasumsikan normal. (2) Multikolinearitas, yang mana pada uji ini dapat dipakai menganalisi suatu model regresi, apakah ada keterikatan atau tidak suatu variabel dependent dengan variabel devendent lainnya. Untuk bisa mendeteksi suatu model regresi tersebut terindikasi multikolinearitas atau tidak, dapat disimpulkan dari nilai tolerance serta nilai VIF, Nilai yang bisa dijadikan acuan untuk pengukurannya adalah: (a) kalau nilai dari tolerance lebih dari 0,10 serta nilai VIF kurang dari 10 maka dapat diambil suatu kesimpulan bahwa tidak ada indikasi multikolonieritas antara variabel bebas dalam model regresi. (b) sedangkan jika nilai tolerance kurang dari 0,10 serta nilai VIF lebih dari 10 maka dapat diambil suatu kesimpulan jika ada indikasi multikolonieritas antara variabel independent dalam suatu model regresi. (3) Uji Heteroskedastisitas, yang mana bisa dipakai untuk menganalisis apakah terjadi suatu penyimpangan model Karen. Pengujian dari heteroskedastisitas dapat dilaksanakan dengan cara melihat dari suatu grafik yang disebut scatter plot pada output SPSS, yang dijelaskan oleh Prayanto (2009) dimana kriterianya adalah sebagai berikut: (a) Ada indikasi heteroskedastisitas dapat dilihat dari titik-titiknya membentuk suatu pola tertentu. (b) sedangkan Jika titik-titiknya tidak berbentuk suatu pola serta menyebar diantara angka 0 pada sumbu $\mathrm{Y}$, maka bisa diambil sebuah kesimpulan jika tidak terjadi heterokedastisitas.

\section{Hasil dan Pembahasan}

Hasil dari pengujian model regresi linier dengan menggunakan bantuan program digital Statistical Package for Social Science (SPSS) 24.0 for windows didapat hasil seperti tabel berikut: 
Tabel 1

Ringkasan Hasil Output SPSS Analisis Regresi Linier Berganda

\begin{tabular}{lcccc}
\hline Variabel Bebas & Koefisien & Sig & $\begin{array}{c}\text { Koefisien } \\
\text { Korelasi }\end{array}$ & $\mathrm{R}^{2}$ \\
Word of Mouth & 0,460 & 0,000 & 0,414 & 0,171 \\
Kualitas Pelayanan & 0,205 & 0,003 & 0,269 & 0,072 \\
\hline Konstanta & 7.405 & & & \\
Sig. F & 0,000 & & & \\
$\mathrm{R}$ & 0,617 & & & \\
$\mathrm{R}^{2}$ & 0,380 & & & \\
\hline
\end{tabular}

Sumber: Hasil Output SPSS 24.0

Berdasarkan pada Tabel 1, dimana mendapatkan nilai konstanta sebesar 7,405. Nilai koefisien dari word of mouth sebesar 0,460 dan nilai koefisien kualitas pelayanan sebesar 0,205 . Maka dapat rumuskan persamaan regresi sebagai berikut:

$$
Y=7,405+0,460 X 1+0,205 X 2+0,620
$$

Sehingga dari persamaan tersebut, menunjukkan bahwa: (1) nilai konstantanya adalah sebesar 7,405 , artinya bahwa jika word of mouth $\left(\mathrm{X}_{1}\right)$ dan kualitas pelayanan $\left(\mathrm{X}_{2}\right)$ nilainya nol, maka nilai keputusan penggunaan $(Y)$ adalah sebesar 7,405. (2) Nilai koefisien regresi dari word of mouth $\left(\mathrm{b}_{1}\right)$ sebesar 0,460 yang mana memiliki arti kalau word of mouth berperan secara positif terhadap variabel keputusan penggunaan $(\mathrm{Y})$. Hal ini artinya jika setiap kenaikan dari word of mouth satu satuan, maka variabel keputusan penggunaan akan meningkat sebesar 0,609 sehingga menjadi sebesar 7,865 $(7,405+0,460)$, dengan anggapan bahwa variabel bebas yang lainnya adalah tetap. (3) Nilai koefisien kualitas pelayanan $\left(b_{2}\right)$ adalah sebesar 0,205 berarti bahwa kualitas pelayanan memiliki peran secara positif terhadap variabel keputusan penggunaan (Y). Hal ini artinya jika setiap kenaikan kualitas pelayanan satu satuan maka variabel keputusan pembelian meningkat sebesar 0,205 sehingga menjadi sebesar 7,610 $(7,405+0,205)$, dengan anggapan bahwa variabel bebas yang lainnya adalah tetap.

Hipotesis yang pertama adalah "Word of mouth dan kualitas pelayanan secara bersama-sama memiliki peran yang signifikan terhadap keputusan penggunaan jasa Gojek di Kota Denpasar". Berdasarkan Tabel 1, nilai koefisien korelasi berganda sebesar 0,617 dengan besar $p$-value adalah 0,000 kurang dari nilai Alpha 0,05, yang artinya menolak Ho, dan berarti ada pengaruh signifikan word of mouth dan kualitas pelayanan terhadap keputusan penggunaan jasa Gojek di Kota Denpasar. Hipotesis yang kedua adalah "Word of mouth berperan secara positif dan signifikan terhadap keputusan penggunaan jasa Gojek di Kota Denpasar". Berdasarkan pada Tabel 1, word of mouth memiliki nilai koefisien korelasi 0,414 dengan besar p-value 0,000 lebih kecil dari nilai Alpha 0,05, yang artinya menolak Ho, dan berarti ada pengaruh positif signifikan word of mouth terhadap keputusan penggunaan jasa Gojek di Kota Denpasar. Hipotesis yang ketiga adalah "Kualitas pelayanan berpengaruh positif dan signifikan terhadap keputusan penggunaan jasa Gojek di Kota Denpasar" Berdasarkan pada Tabel 1, kualitas pelayanan memiliki nilai koefisien korelasi 0,269 dengan besar p-value 0,003 lebih kecil dari nilai Alpha 0,05 hal ini artinnya menolak $\mathrm{Ho}$, dan berarti ada pengaruh positif signifikan kualitas pelayanan terhadap keputusan penggunaan jasa Gojek di Kota Denpasar.

Berdasarkan hasil penelitian yang telah dilaksanakan, hasil penelitian ini menyatakan bahwa variabel independent word of mouth dan kualitas pelayanan secara simultan memiliki peran yang signifikan terhadap keputusan penggunaan. Hasil penelitian ini menunjukan apabila 
variabel word of mouth dan kualitas pelayanan mengalami kenaikan atau penurunan simultan maka akan berpengaruh terhadap keputusan penggunaan.

Gojek dalam upaya untuk meningkatkan penggunaan jasa dari konsumen berusaha menciptakan word of mouth atau komunikasi mulut ke mulut yang positif di masyarakat. Terbentuknya word of mouth yang baik akan mempengruhi calon konsumen untuk melakukan penggunaan jasa, karena hal-hal positif yang tersebar tentang perusahaan akan membuat calon konsumen menjadi tertarik untuk menggunakan jasa tersebut. Word of mouth juga bisa dijadikan media promosi yang gratis, karena konsumen yang pernah menggunakan jasa Gojek dan merasa puas terhadap apa yang didapatkannya maka konsumen tersebut akan dengan sukarela meceritakan pengalamannya menggunakan jasa Gojek kepada orang lain. Gojek dalam upaya untuk meningkatkan penggunaan jasa dari konsumen harus dierhatikannya kualitas layanan yang diterima konsumen dari para pengemudi gojek. Kualitas pelayanan adalah sebuah nilai evaluasi yang menjadi tolak ukur apakah konsumen merasa puas dengan pelayanan yang telah didapatkan setelah menggunakan suatu jasa atau produk. Ketika konsumen merasa puas akan apa yang didapatkan dari pelayanan yang diberikan oleh pengemudi Gojek maka konsumen tersebut akan menggunakan kembali jasa Gojek. Terciptanya word of mouth atau komunikasi mulut ke mulut yang positif serta kualitas pelayanan yang baik akan sangat menentukan konsumen dalam menentukan keputusan penggunan jasa. Hal ini sudah dibuktikan dalam penelitian Saputra \& Ardani (2020) yang mana menyatakan jika variabel komunikasi mulut ke mulut dan kualitas layanan sama-sama memiliki peran secara positif dan signifikan terhadap variabel keputusan penggunaan. Penelelitian lain oleh Sari dan Dwiya (2018) yang menyatakan kalau komunikasi mulut ke mulut dan kualitas layanan memiliki peran yang positif dan signifikan terhadap variabel keputusan penggunaan.

Berdasarkan hasil penelitian yang sudah dilakukan, hasil dari penelitian ini memperlihatkan bahwa variabel word of mouth memiiki peran yang positif dan signifikan terhadap keputusan penggunaan jasa Gojek di Kota Denpasar. Hasil dari penelitian ini juga memperlihatkan jika dengan meningkatnya word of mouth maka akan berdampak terhadap meningkatnya keputusan penggunaan. Sehingga, hipotesis yang awalnya telah dirumuskan sesuai dengan hasil tersebut. Terciptanya komunikasi yang baik tentang jasa Gojek nantinya akan menetukan apakah konsumen akan menggunakan jasa tersebut atau tidak. Konsumen yang pernah menggunakan jasa Gojek akan memberikan informasi terhadap jasa perusahaan kepada orang terdekat, baik itu kepada teman, keluarga atau rekan kerja apakah jasa tersebut baik atau buruk yang nantinya akan mempengaruhi mereka apakah ikut menggunakan jasa tersebut atau tidak. Konsumen yang merasa puas terhadap apa yang didapatkannya saat menggunakan jasa Gojek akan menceritakan hal tersebut kepada orang-orang terdektanya, sehingga orang-orang yang mendengar hal-hal positif tentang jasa Gojek akan tertarik untuk menggunakan jasa tersebut.

Semakin sering orang-orang membicarakan hal-hal yang positif tentang jasa Gojek maka semakin banyak juga calon konsumen tertarik untuk ikut memakai jasa Gojek. Word of mouth yang terbentuk ini akan menjadi sarana promosi yang efektif dan efesien karena konsumen yang puas akan dengan sukarela menceritakan pengalamannya kepada orang lain tanpa mendapatkan insentif apapun dari perusahaan. Gojek harus senantiasa memberikan yang terbaik kepada konsumen, karena hal tersebutlah yang akan menciptakan word of mouth yang positif. Hal ini sesuai dengan pernyataan oleh (Sernovitz, 2009:19) Word of mouth atau komunikasi mulut ke mulut yang bisa membuat suatu percakapan yang baik, dimana orangorang akan mulai bertanya dengan orang terdekatnya perihal mutu suatu barang atupun jasa sebelum mereka menggunakannya. Dengan demikian komunikasi mulut ke mulut bisa mempengaruhi seseorang untuk melaukan keputusan penggunaan. Sejalan dengan penelitian Iknesya dan Arjuna (2019) serta Sari dan Dwiya (2018) yang menyatakan bahwa variabel komunikasi mulut ke mulut memiliki peran yang positif dan signifikan terhadap variabel keputusan penggunaan. 
Berdasarkan dari hasil penelitian yang sudah dilaksanakan, penelitian ini menunjukan jika kualitas pelayanan memiliki peran yang positif signifikan terhadap keputusan penggunaan jasa Gojek di Kota Denpasar. Hasil penelitian ini menunjukan dengan meningkatnya kualitas pelayanan maka akan berdampak terhadap meningkatnya keputusan penggunaan. Sehingga, hipotesis yang dirumuskan sesuai dengan hasil tersebut. Kualitas pelayanan adalah sebuah nilai yang menjadi tolak ukur apakah konsumen puas atau tidak dengan pelayanan yang telah didapatkan setelah menggunakan suatu jasa atau produk. Konsumen yang mendapati dirinya puas dengan pelayanan yang diberikan oleh pengemudi Gojek akan kembali menggunakan jasa dari Gojek di kemudian hari. Akan tetapi jika layanan yang diterima konsumen dari pengemudi Gojek kurang berkesan atau bahkan mengecewakan maka konsumen akan berpindah ke penyedia jasa yang lain.

Gojek memiliki 5 jenis layanan utama yaitu, pelayanan antar jemput penumpang atau GO-RIDE, layanan memesan dan mengantarkan makanan atau GO-FOOD, pelayanan pengiriman barang dari konsumen atau GO-SEND, pelayanan berbelanja atau GO-SHOP dan pelayanan pembelian obat serta kesehatan lainnya atau GO-MED. Pada masa pandemi tahun 2020 yang mana diterapkannya kebijakan Pembatasan Kegiatan Masyarakat (PKM) di Kota Denpasar, maka fitur GO-FOOD dan GO-SHOP akan menjadi fitur yang paling dibutuhkan, karena masyarakat Kota Denpasar akan dengan mudah dapat berbelanja makanan dan kebutuhan sehari-hari tanpa perlu keluar rumah. Keputusan penggunaan oleh konsumen akan sangat ditetukan oleh bagaimana pelayanan yang diberikan oleh pengemudi Gojek. Oleh karena itu Gojek perlu menekankan pengemudinya untuk selalu menyediakan layanan yang maksimal kepada konsumen yang menggunakan jasa Gojek. Pelayanan yang maksimal dan optimal akan membuat konsumen puas dan senang sehingga terus menggunakan jasa Gojek dalam mendukung segala aktivitasnya.

Hasil dalam penelitian ini didukung oleh penelitian yang dilaksanakan oleh Arifin (2017) yang memaparkan kan jika kualitas layanan memiliki peran yang positif dan signifikan terhadap variabel keputusan penggunaan. Sejalan atas penelitian yang dilaksanakan oleh Amrullah (2016) yang memaparkan jika kualitas pelayanan berperan secara positif dan signifikan terhadap variabel keputusan penggunaan. Artinya jika nilai suatu layanan semakin baik maka konsumen tertarik untuk menggunakan suatu jasa atau produk tersebut. Oleh karena hal tersebut konsumen dalam melakukan penggunaan jasa Gojek di Kota Denpasar memiliki peranan yang sangat penting dalam keberlangsungan dari usaha Gojek tersebut.

\section{Simpulan dan Saran}

Berdasarkan dari hasil dari penelitian yang sudah dilaksanakan serta pembahasan yang telah diuraikan diatas, maka dapat ditarik kesimpulan sebagai berikut: (1) Word of mouth dan kualitas pelayanan memiliki peran yang signifikan terhadap keputusan penggunaan jasa Gojek di Kota Denpasar. (2) Word of mouth memiliki peran positif signifikan terhadap keputusan penggunaan jasa Gojek di Kota Denpasar. (3) Kualitas pelayanan memiliki peran positif signifikan terhadap keputusan penggunaan jasa Gojek di Kota Denpasar.

Berdasarkan simpulan di atas, penulis dapat mengajukan beberapa saran bagi perusahaan maupun bagi peneliti berikutnya. (1) Bagi Peneliti selanjutnya keterbatasan penelitian ini hanya mengangkat variabel independent word of mouth dan kualitas pelayanan terhadap keputusan penggunaan serta objek pengguna Gojek di Kota Denpasar. Bagi peneliti selanjutnya yang tertarik untuk menganalisis konteks yang serupa tentang keputusan penggunaan, untuk bisa mengembangkan penelitian dengan menggunakan variabel kepercayaan merek, brand image, citra perusahaan, kualitas produk dan pemasaran digital serta objek peneltian yang berbeda seperti wilayah provinsi Bali lainnya ataupun wilayah Provinsi Bali secara keseluruhan untuk memperoleh hasil yang lebih bervariatif yang dapat menggambarkan variabel-variabel yang akan mempengaruhi keputusan penggunaan. (2). Bagi pihak Gojek diharapkan perusahaan lebih memperhatikan dan mempredikisi word of mouth 
yang tersebar dalam masyarakat karena word of mouth merupakan sarana promosi yang tidak memakan biaya sehinggan hal-hal positif yang tersebar di masyarakat mengenai jasa Gojek akan merangsang calon konsumen untuk melakukan pembelian atau menggunakan jasa dari Gojek. Selain itu kualitas pelayanan yang bagus tentunya akan membuat pelanggan menggunakan kembali jasa Gojek sehingga kedepannya Gojek akan terus berkembang.

\section{Daftar Pustaka}

Amrullah. 2016. Pengaruh Kualitas Produk Dan Kualitas Layanan Terhadap Keputusan Pembelian Sepeda Motor Honda. Jurnal Ekonomi Dan Manajemen. ISSN Print 19073011, ISSN Online 2528-1127, 13(2), 99-118.

Andy, Sernovitz. 2010. Word Of Mouth Marketing : How Smart Companies Get People Talking (Revised Edition). New York : Kaplan Publishing.

Arifin, M. Z., \& Azhari, P. 2017. Pengaruh Kualitas Pelayanan Terhadap Keputusan Pembelian Konsumen Di Alfamart Kota Palangka Raya. Jurnal Al Qardh, v(2), 116-123.

Baskara, Garylda Chrisnatha, Dkk. 2014. Pengaruh Brand Trust dan Kualitas Pelayanan Terhadap Keputusan Penggunaan Pengiriman Paket Pada PT. Jalur Nugraha Ekakurir (JNE) Semarang. Journal Of Social And Political Of Science. Hal. 1-9. http://ejournals1.undip.ac.id/index.php/

Finanda, Iknesya Rahma dan Arjuna W. 2019. Pengaruh Word Of Mouth Dan Brand Image Terhadap Keputusan Penggunaan Salon Kecantikan Pada Konsumen Mil Off Beauty Bar. Jurnal IImiah WIDYA Ekonomika 225. Volume 1 Nomor 2.

Habir, Hastuti \& Zakiyah Zahara F. 2018. Pengaruh Citra Merek Dan Word Of Mouth Terhadap Keputusan Pembelian Sepeda Motor Yamaha. Jurnal IImu Manajemen Universitas Tadulako. Vol. 4, No. 3

Kotler, Phillip dan Kevin Lane Keller. 2009. Manajemen Pemasaran. Edisi 13. Jilid 2. Alih Bahasa: Bob Sabran. Erlangga. Jakarta.

Lukiana, Ninik. 2018. Faktor - Faktor Yang Mempengaruhi Keputusan Pemakai Jasa Indihome Di Lumajang. STIE Widya Gama Lumajang. Vol. 02, No. 02.

Nasution, Herlina, dkk. 2018. Pengaruh Kualitas Pelayanan Dan Harga terhadap Keputusan Pembelian Customer Serta Dampaknya pada Kepuasan Pelanggan (Studi Kasus : Maskapai PT. Lion Air Jakarta). Ekobisman-Jurnal Ekonomi Bisnis Manajemen Vol 3 No 2

Rambat Lupiyoadi dan A. Hamdani. 2008. Manajemen Pemasaran Jasa. Jakarta. Salemba Empat

Sugiyono. (2018). Metode Penelitian Kuantitatif.Bandung: Alfabeta.

Santoso, Singgih.. 2001. SPSS Versi 11,5 Mengolah Data Statistik Secara Profesional. Jakarta: PT Elex Media Komputindo.

Saputra, Gede W. \& I Gusti Agung Ketut S. A. 2020. Pengaruh Digital Marketing, Word Of Mouth, Dan Kualitas Pelayanan Terhadap Keputusan Pembelian. E-Jurnal Manajemen. Vol. 9, No. 7

Supranto, J dan Nanda Limakrisna. 2011. Perilaku Konsumen \& Strategi Pemasaran; Untuk Memenangkan Persaingan Bisnis. Jakarta : Mitra Wacana Media. 